同種造血幹細胞移植後 HBV 再活性化を認めた MDS 患者における HBV 血清学 的マーカーの推移

\author{
初瀬真弓, 淵田真一, 岡野 晃, 村頭 智, 島崎千尋 \\ 独立行政法人地域医療推進機構京都鞍馬口医療センター血液内科
}

HBV 既感染患者において造血幹細胞移植後にHBV が再活性化し de novo 肝炎を生じることが知られている。今回, 同種移植後に HBV 再活性化を認め, re-seroconversion までの推移を追跡した症例を報告する。患者は 39 歳，男性。 骨髄異形成症候群（RAEB-1）に対して HLA 一致同胞の姉より同種末梢血幹細胞移植を実施した。患者は HBV 既感 染, ドナーは未感染であった。移植後 12 か月目に HBsAb が消失したため entecavir（ETV）の予防投与を開始した。 以降 HBV-DNA は陰性が持続し cyclosporine も中止しえたため 10 か月間の投与後 ETV を中止した。移植後 2 年目に HBV ワクチンを 2 回接種したが, 移植後 2 年 5 か月目に再活性化を認め ETV を再開した。ETV開始後 2 か月目に HBV-DNA は陰性化, 4 か月目には HBsAb が陽性化し re-seroconversion に至った。（日本造血細胞移植学会誌 6 (3)： 142-145, 2017.)

\section{はじめに}

HBV 既感染患者において化学療法後や造血幹細胞移植 後にHBVが再活性化し de novo 肝炎を生じることが知られ ている ${ }^{1,2}$ が, 治療介入後の HBV 血清マーカーの推移につい ての報告は少ない。今回, 同種移植後に HBV 再活性化を 認め, HBV re-seroconversion までの HBV 血清マーカーを追 跡した症例を報告する。

\section{症例}

患者：39 歳 (移植時), 男性

現病歴：2010 年 1 月, 骨髄異形成症候群 (WHO 分類 2008 RAEB-1）に対して HLA 一致同胞の姉より同種末梢血幹細 胞移植を実施した（Figure 1)。移植前処置は fludarabin+ busulfan, GVHD 予防は cyclosporine (CyA) および短期 methotrexateで実施した。患者の移植前の HBVマーカーは, HBsAg 陰性, HBV-DNA 陰性, HBsAb 陽性（PHA 法 1,024 倍), $\mathrm{HBcAb}$ 陽性 (9 S/CO) で既感染であり, ドナーはワ クチン接種歴がなく $\mathrm{HBsAg}, \mathrm{HBcAb}, \mathrm{HBsAb}$ いずれも院 性で未感染であった。移植後 6 か月目に慢性 GVHD（肝蔵 スコア 1）を認めたが追加治療なく軽快した。移植後の
$\mathrm{HBsAb}$ 価は漸減し, 移植後 12 か月目にHBV-DNA は陰性 であったが, HBsAb が消失したため entecavir（ETV）の予 防投与を開始した。移植後 1 年 3 か月目には慢性 GVHD は 安定しておりCyA は中止された。以降 HBV-DNAの陰性が 持続しており移植後 1 年 10 か月目にETVを中止した。移 植後 2 年と 2 年 1 か月目に HBV ワクチンを接種したが, 移植後 2 年 5 か月目に HBV-DNA $5 \log$ copies/mL と再活性 化を認めた。肝機能に異常を認めなかったが, HBVのマー カーは HBsAb および HBcAb 陰性, HBeAg 陽性, HBeAb 陰 性であり ETVを再開したところ，移植後 2 年 7 か月目に HBV-DNA は陰性化し, 移植後 2 年 9 か月目に re-seroconversion を確認したため 6 か月間の治療後 ETVを 中止した。

\section{考察}

化学療法や免疫抑制時の HBV の再活性化が注目されて いるが ${ }^{1-9,13}$ (Table 1), ドナー免疫が再構築する同種移植後 における HBV マーカーの推移や至適治療期間などについ ては明らかではない。Onozawa らは同種移植を実施した既 感染患者 14 人中 12 人で $\mathrm{HBsAb}$ の消失を認め, そのうち 7 人に再活性化を認めたと報告した。HBsAbの消失時期は平

Submitted January 23, 2017; Accepted April 1, 2017; Published online, July 18, 2017. (Handling Editor: Hiroatsu Iida, National Hospital Organization Nagoya Medical Center)

Key words: HBV reactivation, Allogeneic hematopoietic stem cell transplantation, HBs antibody, HBV re-seroconversion

Correspondence: Mayumi Hatsuse, Department of Hematorogy, Japan Community Health care Organization, Kyoto Kurakumaguchi Medical Center, 27 Koyamashimofusa-cho, Kita-ku, Kyoto, 603-8151, Japan. E-mail: mayutaro_h@ hotmail.com dx.doi.org/10.7889/hct-17-001 (C) The Japan Society for Hematopoietic Cell Transplantation. 


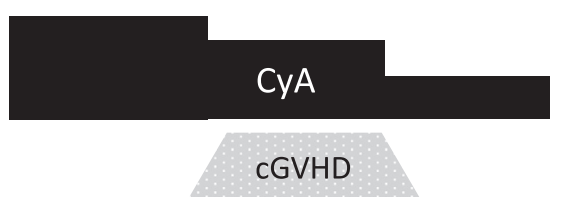

\section{Clinical course}

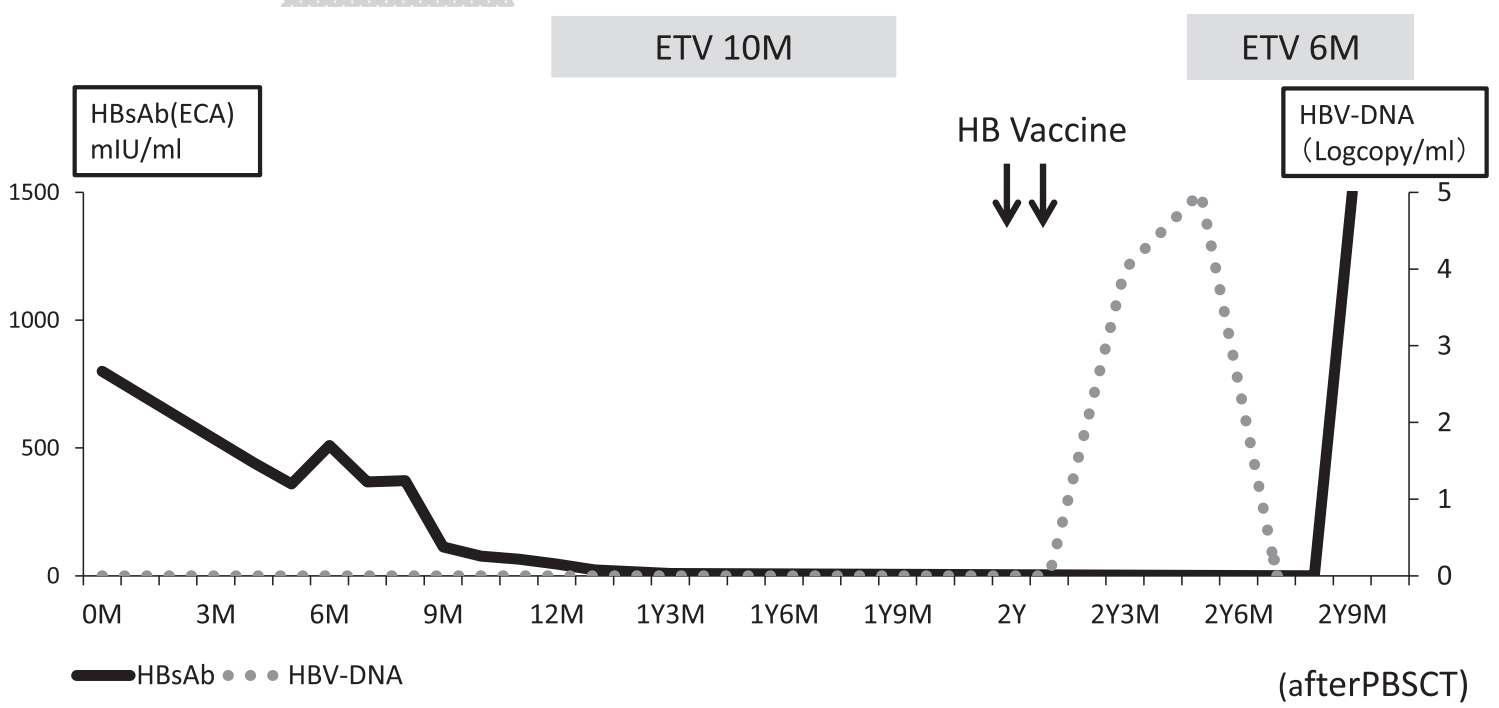

Figure 1. Clinical course. CyA, cyclosporine; GVHD, graft versus host disease; ETV, entecavir; PBSCT, peripheral blood stem cell transplantation

Table 1. Reports of reactivation in HBV resolved patients after allogeneic transplantation

\begin{tabular}{|c|c|c|c|c|c|}
\hline & Total HSCT & $\begin{array}{c}\text { HBV } \\
\text { Resolved Pt }\end{array}$ & $\begin{array}{l}\text { Reactivation } \\
\text { N (\%) }\end{array}$ & Time of reactivation & outcome \\
\hline $\begin{array}{l}\text { Seth } 2002 \\
\mathrm{BMT}^{3}\end{array}$ & 128 & $\begin{array}{c}54 \\
(42 \%)\end{array}$ & $\begin{array}{l}6 / 42 \\
(14 \%)\end{array}$ & $\begin{array}{c}18 \mathrm{M} \\
(5.5 \sim 23 \mathrm{M})\end{array}$ & $\begin{array}{l}5: \text { virological response } \\
1: \text { death }\end{array}$ \\
\hline $\begin{array}{l}\text { Onozawa } 2005 \\
\text { Transplantation }\end{array}$ & 56 & $\begin{array}{c}14 \\
(25 \%)\end{array}$ & $\begin{array}{c}7 \\
(50 \%)\end{array}$ & $\begin{array}{c}20 \mathrm{M} \\
(12 \sim 51 \mathrm{M})\end{array}$ & $\begin{array}{l}5: \text { reseroconversion } \\
2: \text { carrier }\end{array}$ \\
\hline $\begin{array}{l}\text { Hammond } 2009 \\
\text { BBMT }^{6}\end{array}$ & 1386 & $\begin{array}{c}61 \\
(4.4 \%)\end{array}$ & $\begin{array}{c}12 \\
(20 \%)\end{array}$ & $\begin{array}{c}17.5 \mathrm{M} \\
(4.4 \sim 46.9 \mathrm{M})\end{array}$ & $7:$ virological response \\
\hline $\begin{array}{l}\text { Giaccone } 2010 \\
\text { BBMT }^{8}\end{array}$ & 117 & $\begin{array}{c}25 \\
(21 \%)\end{array}$ & $\begin{array}{c}11 \\
(44 \%)\end{array}$ & NA & NA \\
\hline $\begin{array}{l}\text { Vigano } 2011 \\
\mathrm{BMT}^{9}\end{array}$ & 231 & $\begin{array}{c}50 \\
(21 \%)\end{array}$ & $\begin{array}{c}6 \\
(12 \%)\end{array}$ & NA & $\begin{array}{l}1: \text { reseroconversion } \\
3: \text { carrier } \\
2: \text { virological response }\end{array}$ \\
\hline $\begin{array}{l}\text { Mikulska } 2014 \\
\text { Clin Microbiol Infect }^{13}\end{array}$ & 764 & $\begin{array}{c}137 \\
(18 \%)\end{array}$ & $\begin{array}{c}14 \\
(10 \%)\end{array}$ & $\begin{array}{c}19 \mathrm{M} \\
(9 \sim 77 \mathrm{M})\end{array}$ & NA \\
\hline $\begin{array}{l}\text { Bae } 2016 \\
\mathrm{BMT}^{7}\end{array}$ & 519 & $\begin{array}{c}92 \\
(18 \%)\end{array}$ & $\begin{array}{l}14 / 52 \\
(27 \%)\end{array}$ & $\begin{array}{c}15 \mathrm{M} \\
(3 \sim 68 \mathrm{M})\end{array}$ & NA \\
\hline
\end{tabular}

均 13 か月（10３8 か月）, 再活性化は平均 20 か月（12〜 51 か月）でHBsAbの消失が先行した ${ }^{4}$ 。Kaloyannidis らは $\mathrm{HBsAb}$ の消失のリスク因子として, 患者年齢 30 歳未満, 幹細胞ソースが骨髄, 慢性 GVHD の存在, ATG の使用を あげており, 消失時期は平均 36 か月であった。またドナー が未感染では 100\%, HBV ワクチン接種者では $78 \%$, 既感 染者では $58 \%$ に HBsAb の消失を認めた 5 。一方再活性化の リスク因子として, Hammond らは移植前患者の $\mathrm{HBsAb}<$ $10 \mathrm{mIU} / \mathrm{mL}$, 慢性 GVHD ${ }^{6}$, Bae らは $\mathrm{HBcAb} \geqq 8 \mathrm{~S} / \mathrm{CO}$ で
ハザード比 7.429 と報告した7。本症例では HBsAb は高值 であったが, ドナーが未感染であること, $\mathrm{HBcAb} \geqq 8$ がリ スク因子であった。

抗ウイルス剤の至適治療期間として免疫抑制剂中止後 1 年 1.5 年の継続が望ましいとされる ${ }^{8}$ 。同種移植後は免疫 担当細胞がドナー型となることや, 免疫抑制郕を使用して いることより HBV 再活性化のリスクは $40 \%$ と高い 1 。また $\mathrm{HBV}$ 再活性化前に HBsAb が消失することより ${ }^{4}$, 本症例で はHBsAbをモニタリングし消失した時点で予防投与を開 
始した。Sethらの報告では 5 例の再活性化に対して lamivudine を投与し全例で HBsAg が陰転化しだ。一方, Hammond らは 11 例の再活性化に対してETV 治療などを行 い7例でウイルス学的奏効を認めた ${ }^{6}$ 。Onozawa らの報告で は再活性化した 7 例中 5 例が re-seroconversion したが 2 例 はキャリア状態となった ${ }^{4}$ (Table 1)。本症例は再活性化後 2 か月と短期間で re-seroconversion を獲得できたが，ワクチ ン接種をしていたことにより boost 効果があったと推測さ れる。Re-seroconverionに至る因子については今後さらなる 検討が必要である。

同種造血幹細胞移植後の B 型肝炎ワクチン接種について は移植後 12 か月以降での接種がすすめられる ${ }^{10}$ 。本症例は 予防投与としてETVを開始した時期と重なり移植後 2 年目 での接種となった。既感染患者で移植後ワクチンを接種し た患者では HBV の再活性化を認めなかったが, ワクチン 非接種患者では39〜 48\% に再活性化を認めたと報告され る $^{11,12}$ 。本症例では 2 回のワクチン接種では抗体価の上昇を 認めなかった要因として HBV 再活性化の時期とワクチン 接種時期が近接していたことなど考えられる。ワクチン接 種後も慎重に HBV-DNA のフォローが必要であること，ま た ETVによる予防投与よりも，HBsAbをモニタリングし 消失する前にワクチン接種といった治療戦略が考えられ た。またドナーが HBV ワクチン接種者あるいは既感染者 であればハザード比 0.12 と再活性化のリスクが低下す $る^{13}$ 。再活性化の予防対策として移植後の患者へのワクチ ン接種の他, 採取前のドナーへのワクチン接種の検討も必 要であると考えられた。

\section{著者役割}

論文執筆は初瀬真弓，島崎千尋が行い，岡野晃，淵田真一が その内容に関する重要な助言を行った。患者診療は初瀬真弓が 担当し, 村頭智, 島崎千尋が診断および治療につき重要な助言 を行った。

\section{利益相反の開示}

本論文において, 各著者とも開示すべき利益相反は存在しない。

\section{文献}

1. 免疫抑制・化学療法により発症する B 型肝炎対策ガイド ライン（http://www.jsh.or.jp/files/uploads/R2-HBV\%20 Ver2.2.pdf) Accessed 2017Jan20.

2. Kempinska A, Kwak EJ, Angel JB. Reactivation of hepatitis B infection following allogeneic bone marrow transplantation in a hepatitis B-immune patient: case report and review of the literature. Clin Infect Dis. 2005; 41: 1277-1282.

3. Seth P, Alrajhi AA, Kagevi I, et al. Hepatitis B virus reactivation with clinical flare in allogeneic stem cell transplants with chronic graft-versus-host disease. Bone Marrow Transplant. 2002; 30: 189-194.

4. Onozawa M, Hashino S, Izumiyama K, et al. Progressive disappearance of anti-hepatitis B surface antigen antibody and reverse seroconversion after allogeneic hematopoietic stem cell transplantation in patients with previous hepatitis B virus infection. Transplantation. 2005; 79: 616-619.

5. Kaloyannidis P, Batsis I, Yannaki E, et al. Allografted recipients immunized against hepatitis B virus are at high risk of gradual surface antibody (HbsAb) disappearance post transplant, regardless of adoptive immunity transfer. Biol Blood Marrow Transplant. 2007; 13: 1049-1056.

6. Hammond SP, Borchelt AM, Ukomadu C, et al. Hepatitis B virus reactivation following allogeneic hematopoietic stem cell transplantation. Biol Blood Marrow Transplant. 2009; 15: 1049-1059.

7. Bae SK, Gushima T, Saito N, et al. The impact of hepatitis B core antibody levels on HBV reactivation after allogeneic hematopoietic SCT: an 11-year experience at a single center. Bone Marrow Transplant. 2016; 51: 1496-1498.

8. Giaccone L, Festuccia M, Marengo A, et al. Hepatitis B virus reactivation and efficacy of prophylaxis with lamivudine in patients undergoing allogeneic stem cell transplantation. Biol Blood Marrow Transplant. 2010; 16: 809-817.

9. Viganò $\mathrm{M}$, Vener C, Lampertico $\mathrm{P}$, et al. Risk of hepatitis B surface antigen seroreversion after allogeneic hematopoietic SCT. Bone Marrow Transplant. 2011; 46: 125-131.

10. 造血細胞移植ガイドライン予防接種 (https://www.jshct. com/guideline/pdf/2008yobousesshu.pdf) Accessed $2017 \mathrm{Feb} 12$.

11. Onozawa M, Hashino S, Darmanin S, et al. HB vaccination in the prevention of viral reactivation in allogeneic hematopoietic stem cell transplantation recipients with previous HBV infection. Biol Blood Marrow Transplant. 2008; 14: 1226-1230.

12. Takahata M, Hashino S, Onozawa M, et al. Hepatitis B virus (HBV) reverse seroconversion (RS) can be prevented even in non-responders to hepatitis B vaccine after allogeneic stem cell transplantation: long-term analysis of intervention in RS with vaccine for patients with previous HBV infection. Transpl Infect Dis. 2014; 16: 797-801.

13. Mikulska M, Nicolini L, Signori A, et al. Hepatitis B reactivation in $\mathrm{HBs} \mathrm{Ag}$-negative/HBcAb-positive allogeneic haematopoietic stem cell transplant recipients: risk factors and outcome. Clin Microbiol Infect. 2014; 20: 694-701. 


\title{
Serological change of Hepatitis B virus (HBV) markers in a patient with myelodysplastic syndrome showing $H B V$ reactivation after allogeneic hematopoietic stem cell transplantation
}

\author{
Mayumi Hatsuse, Shin-ichi Fuchida, Akira Okano, Satoshi Murakami, Chihiro Shimazaki \\ Department of Hematology, Japan Community Health care Organization, Kyoto Kuramaguchi Medical Center
}

\begin{abstract}
Patients with resolved Hepatitis B virus (HBV) infections are at a high risk of HBV reactivation and de novo HBV infection after allogeneic stem cell transplantation; therefore, it is important to carefully monitor HBV serological markers in these patients.

A 39-year-old man diagnosed with myelodysplastic syndrome and refractory anemia with excess blasts (RAEB-1), received a peripheral blood stem cell transplant from an HLA-matched sibling. The patient had latent HBV infection, while his donor had no history of HBV infection. Twelve months after the transplant, the patient tested negative for $\mathrm{HBsAb}$ and he received entecavir (ETV) as prophylaxis for HBV recurrence. Cyclosporine was discontinued 15 months after transplantation. ETV was discontinued after 10 months of treatment because serum HBV-DNA was not detected. Moreover, 2 years after the transplant, the patient underwent HBV vaccination. However, HBV reactivation occurred 29 months post-transplantation, and ETV was readministered. Two months after starting ETV treatment, HBV-DNA was not detected but 4 months later, re-seroconversion occurred and the patient tested positive for HBsAb.

This case suggests that serological HBV markers should be monitored carefully in patients with resolved HBV infections who received allogeneic stem cell transplants. HBV vaccination is recommended for these patients after immunosuppressive medication is discontinued. (Journal of Hematopoietic Cell Transplantation $6(3)$ : 142-145, 2017.)
\end{abstract}

